\title{
Bundo Kanduang in Minangkabau Novels in the Old Order
}

\author{
Irfani Basri, Ellya Ratna, and Zulfikarni \\ Indonesian literature department \\ FBS Univeristas Negeri Padang \\ Padang, Indonesia \\ irfanibasri@gmail.com
}

\begin{abstract}
The aim of this research is to describe the role and position of Bundo in Minangkabau novels which written in old order and new order. The specific purpose is to describe the facts, traits and relationships between the phenomena investigated systematically, factually, and accurately. This qualitative research has data in the form of words or images, not in the form of numbers.It is use analysis approach because it is probe of the roles in the data or sources. From the findings and the results of the research data on the novels Minangkabau Bundo kanduang as the main women is easy to get a decent place and preferred, but it is only a symbol. It is seen from their daily life that take care of the household, without being able to determine a decision, including in choosing their mate. Furthermore the suppression of women was found. It is done by men, both members of the family like panghulu and son, or a person outside the family. However, its also found in some novels that women get their freedom in determining opinion and decision in their way. They can determine their life and their mate, moreover they have dared to refuse the rules that they think it disadvantage for people. Other than that, in some novels easy to find the women who work an not only to taking care of the household, but can be involved in the society.
\end{abstract}

Keyword: role, position of Bundo Kanduang, novel, the old order

\section{INTRODUCTION}

Minangkabau for Minangkabau people serve as a view of life that base on the mind which get a primary position in the society of mannered and religion. The tradition is something to regulate a live and people live in order to be polite and peaceful without deny the religious, legality, and social. In other words, Minangkabau custom used to an unwritten measure to be followed by every people in that society.

Minangkabau culture also discussed in the literary (novel). Novels as literary provide an opportunity for authors to convey issues that observed, discovered, and perceived. This is due to the existence of the author as a social being. Esten (1988: 12) explained that the existence of an Indonesian writer is an artist of two worlds: the world of their culture and the new world of Indonesia. The works he created will not escape from cultural value of the writer came from.

It is not surprising that the Indonesian literature writers will appear from the ethnic minangkabau who talked about Minangkabau tribe, even though they obtained their education in outside. Moreover, they are bringing improvement and creativity. One of the creativity is a novel. Among the Indonesian writers who made Minangkabau cultural as the source of creation are Marah Rusli (Siti Nurbaya), Sutan Sati (Sengsara Membawa Nikmat), Hamka (Tenggelamnya Kapal Van der Wijck), A.A. Navis (Kemarau) and Wisran Hadi (Orang-orang Blanti), and many other authors who write based on an Minangkabau culture.

Since the 20s era, the literary works (the novel) is discussing about the problems of the Minangkabau people as a matrilineal society, and also about women as people who are worth considering in Minangkabau culture. Siti Nurbaya and Salah Asuhan are two famous novels. The two novels discuss about minangkabau ethnic which controversial and give rise to debate. By reading the novel, there will be a change of mindset and cultural orientation of the reader. This proves that the novel is not only based on the imagination of the author, but also based on the reality that developed in society.

Many literary works of Minangkabau culture that has been published and received various awards, so the authors wanted to examine the role and position of women as the figure in that novels. The selection of these novels is based on the cultural issues who raised by the author. The aim of analysis novels of local Minangkabau in the Old Order era is to find the role and position of women.

\section{Culture in literature}

Culture can be seen from a wide and narrow. Koentjaraningrat (1974: 1) explain that in the narrow sense of culture is a mind, work, and the masterpiece who fulfills of magnificence. Because it is one of a cultural aspects. On the other way culture is a thoughts, works, and the masterpiece who is not based on instincts. therefore, it can be make by humans learning process. 
Louis (1970: 60) formulates the characteristics of culture. First, culture is a way of life. Second, culture is the whole of the plan or the design of life. Third, the functional culture is organized in a system. Fourth, culture is gained through learning. Fifth, culture is the way of life of a social group or group, not an individual or individual way of life.

Maran (2000: 27) explains that culture is a unity composed of different parts. The parts that make up the culture are integrated and interconnected. It will Changed one part to other parts and will affected the whole system. The Values are an idea of something good, to be expected. They are the formation of social norms, how the role of person behave. These values and norms differ from one culture to another.

Cultural analysis is an analysis of the forms that used by a particular group of people. Literature as a cultural product can not stand alone. There is an interrelated relationship among these cultures (Yusriwal, 2004: 171). The culture background in novel is Minangkabau The intersection between the novel and the literary works of culture in the Minangkabau society will be seen in the literary work.

Novels has created by authors derive from the realities which exist in people's lives. Novel is expected to provide some values to the readers especially for life issues other than entertainment. Thus, the novel as a literary product is expected to serve as a mirror in behaving for society. If a function has been achieved by itself, it will be a useful and good value for the reader.

\section{Culture type in Bundo Kanduang Position}

Bundo kanduang is a women calling according to Minangkabau custom. The meaning of bundo is a mother, kanduang means true. So, Bundo Kanduang is a true mother who has a character of motherhood and leadership based on Minangkabau custom role. Meanwhile, according to Gouzali (2004: 60) stated that Bundo Kanduang is the mother who birth or biological parents.

Further Idrus (2004: 69-70) argues that Bundo Kanduang as the mother where pulling the consanguinity of Minangkabau society a phrase that; Bundo kanduang, limpapeh rumah nan gadang, umbun puruak pagangan kunci, umbun puruak aluang buniang, java pus a collection of ropes, sumarak in kampuang, ornaments in nagari, nan gadang basa batuah, kok hiduik tampek banasa, how to die bekik, kaundang kamadinah, kapayuang pennant ka sarugo. (women or mother, the light in the society, the key holder, the main center of survival in the household, the embellishment in society, the problem solving, the bearer to the path of truth, the role model in life.)

From the statement above can be concluded that a Bundo Kanduang have double duty. First, Bundo Kanduang as the center of all power in the society. Secondly, she must be able to be a good wife for her husband. Third, she will organize all of household needs and be an model for members of her society. Fourth, a Bundo Kanduang is a person who can socialize in the society where she lived. Fifth, bundo kanduang is a symbol of pride and glory that is the intermediary of the breed raised and respected, so she is required to have a good personality. And sixth,Bundo Kanduang should required to direct her members toward the happiness.

Furthermore Idrus (2004: 77-80) states that a Bundo Kanduang must have the qualities of leadership and motherhood as follows:

1) Properly

Bundo kanduang has true character. That is, true in speech and behavior. Beside that It always educated people in their society with the truth.

2) Bundo Kanduang should honest and believable.

Bundo Kanduang has an honest nature. It means should be honest in the words and educate the society with good model and actions. Bundo Kanduang will rejected all of acts that are contrary to honesty such as stealing, cheating, and other bad traits.

3) Being smart

Bundo kanduang must be clever. it means having the nature of know and clever. Knowing means know everything that is useful or not. Know means has knowledge in the household and the environment, it is about education and experts in femininity and also in customs and religion and the state. Clever should always put everything in good place and consort with people.

4) Good speaking

Bundo kanduang must be a good speaking. It means Bundo Kanduang must be fluent in words because Bundo kanduang serves as educators both in the household and in his people.

5) Shyness

Bundo kanduang must has Shyness. The shy of women will be regarded as a virtuous woman as the saying; rarak kalikia dek binalu / tumbuah sarumpun jo sikasek / kok lah hilang raso jo malu / bak kayu lungga pangabek. It means if a bundo kanduang does not have the shy nature, so her life will be broke.

\section{Objects and Research Data}

The object of this research is all of the events that experienced by storytellers in local novels of Minangkabau which published during the Old Order. The data of this research are words, phrases, clauses, and sentences that state the role and position of Bundo kanduang. In addition, research data is a form of data which generated intuitively by researchers and triangulated to the experts of the field of literature. 


\section{Role and Status of Women as Bundo Kanduang}

The position of women in Minangkabau as Bundo Kanduang in the local figure in novels of Minangkabau in the Old Order era will be described in the following explanation.

the Status expression of Women as Bundo Kanduang in the novel Warisan Karya Chairul Harun.

\section{a. As a Wife}

A Bundo Kanduang should be able to be a good wife for her husband. Bundo kanduang is the person who will manage all the household needs and be a role model for members of his people. The role of women as a Bundo Kanduang does not all appear in the character of the story in the novel Warisan. As the author submitted through the following quotation. "Last night your husband was shouting for you. Where are you? "mommy order As to come home" (Aaron, 1979: 71)

The author also describes women who do not do their role as a wife. It was described by Navis through the Asnah figure. Asnah does not accompany her husband when her husband at the last gasp.

Furthermore, it is also described a woman who doing her duties as a wife. As a wife, women should be able to serve their husband, whether in happy conditions or not. If only accompanying her husband in a glad and leave it in a difficult situation, people will label the woman is not a good women. To be more clear, can be seen in the following excerpt.

If she became a widow because I died, then her name will be good. He will be considered a decent woman to her husband, not leaving her husband in distress. (Aaron, 1979: 69)

b. As Mother

As a mother to her children in his society, Bundo Kanduang should required to direct her members to the happiness. Novel Warisan by Chairul Harun also shows the role and position of women as mother in family. Like the following quote. When he was leaving, her mother had warned do not talking and involving in treasures, either high or low inheritance or low inheritance. "Raf, we never expect your father's inheritance," said his mother. (Aaron, 1979: 70). Through that quotation it can be seen that a mother does not teach greed to her child. Mrs. Rafilus reminded her son not having a set to heritage treasures. Mrs. Rafilus wishes her son can bring his father to go to Jakarta. As a mother, she only her husband healthy.

Based on that quotations in the novel Warisan, it be founded that women as bundo kanduang is already in a role, either become a wife or become a mother. However, there are also women who only reap the benefits of her husband, especially in terms of material, he can not be able to accompany her husband when in distress.

2. The Position of Women as Bundo Kanduang in the Novel Kemarau Karya A.A. Navis

a. as a Wife

The figure of a woman in kemarau novel by Navis described as an independent wife and others especially for her husbands. Women are used to hard and challenging lives. They prefer to divorce with their husbands rather than live in dishonest and hurt her. For them divorce is a whip to live more independently with her children. It can be found in the following novel excerpt.

They are not afraid of life rather than pain. It is not necessary to publish compassion. In addition to the fact that it was commonplace in the village, the women there never rely solely on their husbands. They will be able to live alone. Instead divorce, is a whip for him to achieve glorious life with his children. (Navis, 1964: 22)

Through the quote, Navis describes an independent women character, in the sense of not depend on her husband. In addition, Navis also describes the figure of a nosy woman, and likes to gossip wherever she is. Besides gossiping, also be fooling facts. This attitude is a bad trait that must be eliminated by a woman as a Bundo Kanduang. Hakimi (2004: 77) said that a women should be honest, and can be trusted. It can be seen through the following quotation.

On the edge of the river, when the women were busy washing and bathing, nor they talk about Sutan Duano. "Sutan Malakewi asked Sutan Duano for Haji Samsiah. But Haji Samsiah, he who proposed Sutan Duano. But he refused. Because he said, it is inappropriate for a Hajj to marry someone who is not Haji. (Navis, 1964: 27-28

"Yes. That's better. "In the yard of a rumah gadang, a group of women who were talking when Sutan Duanoto leaves (Navis, 1964: 60)

b. As Mother

Next, Navis also describes the figure of women who lack understanding of religion, and weak spirit to reach a better hope in the future. They also lazy to explore their potential within them. They live in a glorious hope. There are many things they can do to earn a better life. They are generally quite content with what is and what is fate, seen through the following quotation. "If the rice fields do not, they will not be anything. They can sell rice to the market like us too. " "We never bought rice from the rice fields of this village, Master." (Navis, 1964: 35).

He looked at her face one by one. He capture their thoughts, desires, and willpower. But it is just as plain as they seem. they are older who feel reached the grave. It is not many young women who still have the future. Most of them are widows. 
Do not change the village, only the parents who always go to surau to hear a religion. While the young think that they will come to soon(Navis, 1964: 31).

In the Kemarau novel also depicted the figure of a nosy woman with the affairs of others, even though neglected her self. They are jealous when they see others better than themselves. They love to compete with others, and try to get rid of them. Navis describe the figures Attitude become out of tune for woman.Furthermore, Navis describes the character's through the following quotation.

"many women as the widow in this village, only the Gudam's field as a teacher which help to pour the water

" said the woman. Then like a snake, he go out from Sutan Duano. (Navis, 1964: 34)

"Why are you to him? But your mother don't want you to go there."' Now it's okay "'you can. Why your mother want you go ther?"" Mak said ... "Acin did not go on." Come here" Saniah approaches Acin. "What's your mother said?. Say to Etek, what's it? "" Say the her, I want learn to her, how to attract the man. (Navis 1964: 49-50)

When women get the role model that will lead them to be a better way, it turns out that they are only fond of the person, not the knowledge. They live by the old way and do not want to change for the better. As seen through the following quote.

The woman in the village is only a follower, not learner. he does not like the worship of people, he does not like the old system of bapakism. (Navis, 1964: 44) Furthermore, Navis also describes women characters who live in jealousy. Through the Saniah, Navis shows the jealousy to achieve the desired goals. Saniah tried to put the ingredients from the shaman under the steps of Gudam's house, its purpose to to get St. Duano. As shown in the following quotation.

"are you Saniah? What are you doing here? "she detach her hand. Then he approached the hole. He took something from it. A small object wrapped in a cloth. And he knew what Saniah meant by planting things under the steps of Gudam's house. (Navis, 1964: 87)

"You're going to spoil somebody else by planting that potion. But actually you're the one who will be broken. God will be anger for you, Saniah. " "Teacher does not understand about women's hearts. Any woman will be brave for her heart. Women will dare to uphold his words that his voice snagged and hoarse. (Navis, 1964: 88)

In addition some attitudes of female figures described, the role and position of women in this Kemarau novel also get less way from her people. Through the figure Gudam describe that women's rights are neglected, both by her husband and her society. For example, in the case of marriage, women are not given the opportunity to determine their soul mate, while when there is a problem, the woman is considered unlucky. As in the following quotation.

when I was married to the father of Acin, no one needed to ask me, whether I liked or not. But after my second child birth, I am divorced, all of them blaming me as a bad lady, who is not clever with my husband. I am suffering with my children but to help us. And now, while I'm poor, everyone agrees to insult me. O, they are shy, they feel humiliated by that incident? Is it their feel ashamed, to feel humiliated? (Navis, 1964: 101)

By looking at some quotations that have been described before, it can be seen that women in carrying out their duties is not as expected of a Bundo Kanduang. Only a few are aware what should they must perform. Its Still found woman who are only concerned with its own affairs, selfish, do not care about the family, and justifies any means to achieve the desired goal.

YELL

\section{THEORETICAL FRAMEWORK}

In Indonesian Language, yell is known as "yel-yel" which means "teriakan". According to Supriadi in Sunarto (2012), yell is one of activities in Icebreaking technique which means ice. It is often used in training so they know each other, understand and can interact to each other. Besides yell, parts of icebreaking activities are song, mime, clap hands technique, etc. Solihan (2011) stated that yell contains shout with motivation words. One of technique that can be used in teaching and learning process is yell. This technique can create an enjoyable atmosphere especially when students learn tenses which are known complicated materials because they are full of formula and rules. Puji in Safra (2016) said that teachers can modify certain songs become yell containing motivation words. They can be performed before learning begins. According to her, they are two kinds of yell. 1) Classroom yell. It is performed to set the condition of learning readiness. 2) Lesson yell. It contains words to motivate students to learn lesson.

There are some purposes of yell. They are: 1) to build learning motivation. 2) To create fun atmosphere in learning. 3) To build good and friendly relationship between teachers and students.

\section{YELL VIDEO}

Students like to learn English by using an interesting medium, one of the media is by using video. Video can make students 
interested in learning. The use of video can create enjoyable atmosphere and avoid boredom in teaching and learning process. If the video contains English materials that are modified with interesting ways, the learning process becomes more fun. Yell videos were created to help the students learn tenses in enjoyable ways.

\section{TENSES}

Tenses discuss about time. Each time has different formulas used. That is why it is important to memorize the formulas of tenses in order to minimize errors in stating an action. Azar (2006) states that there are twelve common tenses used in English. They are:

1. Simple present

It is used to state actions in the presents, habits, or general truth.

Nominal form (no verb)

For example: I am busy

Verbal form (uses verb)

For example: We go to cinema every week

2. Present progressive

It is used to state that an action has started, but it has not finished yet. It is happening now and we are in the middle of it. For example: They are playing volleyball

3. Present perfect

It is used to state an action in a period leading up to the present, a series of actions before now, and an event lasting up to the present.

Nominal form

For example:YongDolah has been in Bangkok

Verbal form

For example: She has taken abath

4. Present Perfect Progressive

It is used for an action over a period of time leading up to the present.

For example:Miley Cirrus has been singing for five years

5. Simple past

It is used for an action in the past.

Nominal form

For example: He was happy yesterday

Verbal form

For example: My mother went to Batam last week.

6. Past progressive

It is used to express the idea that at a time in the past we were in the middle of something when another action took place,

For example: I was teaching English when John came

7. Past perfect

It is used to state that an action had finished when another action occurred in the past.

Nominal form

For example: I had been in office before Sue came

Verbal form

For example:Milla had left after his friend arrived

8. Past perfect progressive

It is used for an action that went on over a period when another action occurred in the past time.

For example:You had been teaching English when the headmaster came

9. Simple future

It states that an action will take place in the future.

Nominal form

For example: Jack will be in America next week

Verbal form

For example: We will buy Grammar Book tomorrow

10. Future progressive

It is used for an action that will be in the middle of when another action occurs in the future.

For example: He will be playing a piano

11. Future perfect

It is used to state that an action is finished in the future when another action happens. 
For example: He will have arrived at 9 a.m

12. Future perfect progressive.

It is used to state that an action has started and still in progress when another action happens in the future.

For example: Amanda will have been repairing his car at the garage.

\section{METHODOLOGY}

In this research, Quasi-Experimental research was used. According to Cresswell(2008: 299), it is used to test an idea (or practice or procedure) to determine whether it is influenced an outcome or dependent variable. An experiment is the quantitative approach that provides the greatest degree of control over the research procedures (L.R Gay, 2000: 15). This research used quasiexperimental design with nonequivalent control group which was an appropriate one to this research in order to find out the significant effect of using yell videos to learn tenses of students at State Polytechnic of Bengkalis.

In this research, there were two classes; one class is an experimental group which was treated by using the Yell Videos and another one is as a control group taught by using non Yell Videos. For both experimental and control groups, pre-test and posttest administered to the students. Pre-test was given at the beginning of the teaching learning in order to identify the students' English in learning tenses. Then, the experimental group was given a treatment by using Yell Videos and the control group using non Yell Video. During the treatment, the writer accompanied by an observer, and at last, both groups was given post-test at the end of the teaching learning processes in order to determine the effect of using yell videos to learn tenses of students at State Polytechnic of Bengkalis. The model of the research design is illustrated in the Table 1 below.

Table 1.. The Research Design

\begin{tabular}{|c|c|c|c|}
\hline Group & $\begin{array}{c}\text { Pre- } \\
\text { test }\end{array}$ & Treatment & $\begin{array}{c}\text { Post- } \\
\text { test }\end{array}$ \\
\hline Experimental group & Test 1 & $\mathrm{X}$ & Test 2 \\
\hline Control Group & Test 1 & - & Test 2 \\
\hline
\end{tabular}

\section{FINDING AND DISCUSSION}

In order to know the effect of using yell video, the data was analyzed by using t-test formula. The researcher used Lilliefors testing for analyzing the normality testing at the level of significance 0.05 . Variance Formula was used to test homogeneity testing. The data analysis can be seen from the table 2 below:

Table 2. Result of t-test for experimental and control group

\begin{tabular}{|c|c|c|c|c|c|}
\hline & $\mathbf{N}$ & Mean & Std.Deviation & Minimum & Maximum \\
\hline Experimental & 26 & 73.35 & 4.995 & 67 & 83 \\
\hline Control & 26 & 59.58 & 3.826 & 50 & 68 \\
\hline
\end{tabular}

The table shows that the total students from each group was 26, the mean score of experimental group was 72.92 , and mean score of control group was 59.58. Standard deviation from experimental group was 4.995, while standard deviation from control group was 3.826. From the output above, it also can be seen that $t_{\text {observed }}=2.09$ compared to $t_{\text {table }}$. The level of significances 0.05 was 1.708. It can be concluded that $2.09>1.708\left(\mathrm{t}_{\text {observed }}>\mathrm{t}_{\text {table }}\right)$. Therefore, null hypothesis $\left(\mathrm{H}_{\mathrm{o}}\right)$ was rejected, while the alternative hypothesis $\left(\mathrm{H}_{\mathrm{a}}\right)$ was accepted. It means there was a significant effect of using yell video on students' grammar ability.

This finding was line with Supriadi in Sunarto (2012) statement that yell was one of activities in Icebreaking technique which means ice. It is often used in training so they know each other, understand and can interact to each other. Besides yell, parts of icebreaking activities are song, mime, clap hands technique, etc. Solihan (2011) stated that yell contains shout with motivation words. One of technique that can be used in teaching and learning process is yells. This technique can create an enjoyable atmosphere especially when students learn tenses which are known complicated materials because they are full of formula and rules.

\section{CONCLUSION}

This research was done at the third semester students of State Polytechnic of Bengkalis, From the result, it can be concluded students' who were taught by Yell Video had better grammar ability in learning tenses than students' who were taught by Conventional Teaching. Students' mean score of experimental class (73.35) who were taught by Yell Video was higher than students in control class (59.58) who were taught by conventional teaching. Yell Video is a good alternative to help students in learning tenses. This techniquecan makes students interested in learning English especially grammar. It is suggested that this technique can be applied by English lecturer. 


\section{References}

Aprizawati, Zahraa,Safra A. (2016). The making of yell videos to learn tenses.P3M: SNIT POLBENG.

Astuti, Puji. (2011). The effectiveness of course review horray in Improving students'simple past tense mastery (an experimental study) at grade XI of SMA Negeri 1 Subah. English Department Faculty of Languages andArts. Thesis.Semarang State University.

Azar, B.S., Hagen, S.A. (2006). Understanding and Using English Grammar.Second Edition. New York: Pearson Education

Creswell, John. W. Educational Research: Planning, Conducting, and Evaluating Quantitative and Qualitative Research Ed 3rd, (Lincoln: Pearson Education International, 2008)

Gall and Borg (2003).Educational research: an introduction. London: Pearson Education.

Jasmansyah(2008).ejournal.undiksha.ac.id/index.php/JJPGSD/article/viewFile/1341/1202. Retrieved on August 20 th, 2016

L. R. Gay and Peter Airasian. 2000: 163-167. Educational Research Competencies for Analysis and Application Sixth Edition.

New Jersey: Pearson Education

Pujiyanti(2013)ejournal.undiksha.ac.id/index.php/JJPGSD/article/viewFile/1341/1202. Retrieved on August 20 th, 2016

Solihan.(2010).AplikasiYelYelMotivasiSebagaiStrategiReenforcementdalamMeningkatkanMotivasiBelajar PAI Siswa di SMA Muhammadiyah 2Sidoarjo.Skripsi.IAINSunanAmpel

Sunarto.(2012). Icebreaker dalamPembelajaranAktif. Surakarta: Cakrawala Media. 